\section{Vuorovaikutuksesta tuoreesti ja käytännönläheisesti}

Klemola, Ulla \& Talvio, Markus (2017). Toimiva vuorovaikutus. PS-Kustannus. 183 sivua.

VAIKKA VIESTINTÄTAIDOISTA ja vuorovaikutuksesta on kirjoitettu paljon oppikirjoja, Ulla Klemola ja Markus Talvio löytävät aiheeseen tuoreita näkökulmia. Kirjoittajat tuntevat vuorovaikutusteemaa tutkijoina, opettajina ja kehittäjinä.

Toimiva vuorovaikutus lähestyy vuorovaikutustaitoja sosioemotionaalisen oppimisen mallin avulla. Taustateoriana on muun muassa yhdysvaltalaisen kliinisen psykologin Thomas Gordonin tunne- ja vuorovaikutustaitoajattelu, joka kytketään sosioemotionaaliseen oppimiseen.

Sosioemotionaalisen oppimisen osa-alueina kirjassa esitellään minätietoisuus, itsensä johtaminen, sosiaalinen tietoisuus, ihmissuhdetaidot ja vastuullinen päätöksenteko. Vastavuoroista vuorovaikutusta tarkastellaan muun muassa näiden osa-alueiden kautta.

\section{OMA ASENNE RATKAISEE}

Kirja korostaa toista ihmistä kunnioittavaa ja tasa-arvoista asennetta vuorovaikutuksen perustana. Epäonnistuneissa vuorovaikutustilanteissa on aina usea osapuoli, joten virheiden etsiminen vain toisten toiminnasta on lyhytnäköistä. Voidakseen arvioida kokonaisuutta on ensin pystyttävä puolueettomasti arvioimaan omaa toimintaansa.
Oppimisprosessissa tietojen, taitojen ja asenteiden avulla voidaan tukea sosiaalista ja psyykkistä hyvinvointia. Yhteisöllisen toiminnan kehittämisen rinnalla teoksessa tarkastellaan vahvasti oman toiminnan säätelyä ja itsereflektointia. Esille nousevat tunteiden tiedostaminen ja tilanteessa myötäeläminen. Vuorovaikutustaitojaan kehittämällä voi lisätä itsetuntemustaan ja syventää ihmissuhteitaan.

Vuorovaikutusta kuvataan usein kuin teknistä suoritusta, vaikka tilannesidonnaisuus ja osallistujat vaikuttavat merkittävästi vuorovaikutustilanteeseen. Muiden käyttäytymiseen ja tekemiseen emme aina voi vaikuttaa, mutta omaa itseä voi tarkastella ja omaa toimintaansa voi parantaa. Omia taitoja kehittämällä on mahdollista tukea muiden osaamista ja parantaa vuorovaikutusta ryhmätilanteessa. Viestijöinä emme koskaan ole valmiita.

Kirjassa käsitellään kattavasti ryhmäviestintää ryhmän rooleista palautteen antoon, päätöksentekoon ja ystävyyssuhteisiin. Huomiota kiinnitetään arvojen merkitykselle vuorovaikutustilanteissa: pohditaan muun muassa niin arvoristiriitojen haasteita kuin toisten arvojen kunnioittamista, vuorovaikutuksen valtasuhteita unohtamatta. Tunnetaidot osana vuorovaikutusta korostuvat sosioemotionaalisen käsittelytavan myötä.

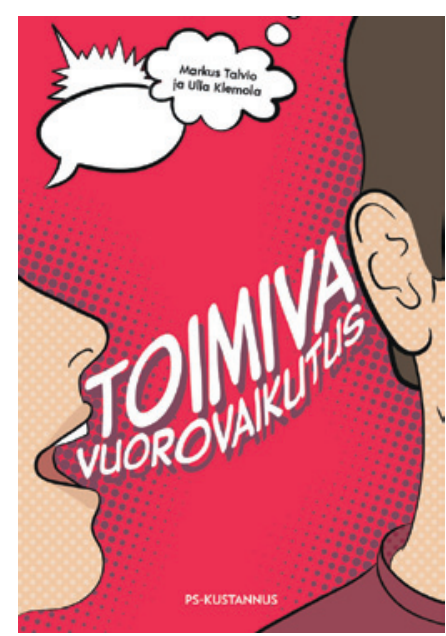

TOIMIVA VUOROVAIKUTUS

VAATII TYÖKALUJA

Kirjan toisessa osassa avataan toimivan vuorovaikutuksen työkaluja, joita ovat esimerkiksi kuuntelun taidot, ongelmanratkaisutaidot, tunneymmärrys sekä tunteiden tunnistaminen ja nimeäminen. Työkalujen moninaisuus korostaa vuorovaikutuksen monisäikeisyyttä ja taitojen moninaisuutta.

Kirjoittajat pohtivat työkalujen yhteiskäyttöä, kuten aktiivisen kuuntelun ja minäviestien vuorottelua. Vuorovaikutuksessa on osattava keskittyä niin itseensä kuin keskustelukumppaneihin. On annettava tilaa toisille unohtamatta itseilmaisua ja omista tarpeista huolehtimista.

Minä ja muut -ulottuvuus korostuu vuorovaikutustilanteessa: on tärkeä kohdata niin omat kuin muiden osapuolten tunteet, kuunnella itseään ja keskustelu- 
kumppaneita sekä johtaa omaa ja muiden toimintaa.

Vaikka olisi opiskellut vuorovaikutuksen teoriaa, ei välttämättä osaa soveltaa oppimaansa käytäntöön. Parhaimmillaan vuorovaikutusosaaminen tukee kasvatus- ja opetustyötä.

\section{TOIMII PALASTELTUNA}

Kirjan monet pohdinta- ja havainnointitehtävät johdattavat aiheeseen ja itsetutkiskeluun. Vuorovaikutus näyttäytyy moniulotteisena tapahtumana, jota muokkaavat osallistujien inhimilliset piirteet ja käyttäytymisen vivahteet. Monet kirjan esimerkit soveltuvat niin koulu- ja työympäristöön kuin vapaa-ajan viestintätilanteisiin.
Toimiva vuorovaikutus sopii laajalle yleisölle, sillä se ei jää yksittäisten tieteenalojen sisäiseksi oppikirjaksi. Vaikka asiat tuntuvat tutuilta, uudenlainen tarkastelutapa haastaa tutustumaan niihin aiempaa syvemmin.

Kirja on helppolukuinen ja selkeä. Sitä voi käyttää käsikirjamaisesti ja hyödyntää yksittäisiä pohdintaharjoituksia. Ammattikorkeakoulun tai yliopiston opetustyöhön se on hyvä työkalu, mutta kirjan antia voi hyödyntää viestinnän opetuksessa myös alemmilla kouluasteilla.

Mukavana lisänä pidän kirjan esimerkkejä eri aloja koskevista vuorovaikutustutkimuksista. Esimerkiksi lääkärin ammatissa puheen pienetkin vivahteet ja kommentit ovat tärkeitä. Kirjassa esitellyt tutkimuksen mukaan potilastyössä tarvittavat vuorovaikutustaidot on mahdollista oppia hyvinkin nopeasti. Eniten koulutuksesta hyötyvät lääkäriopiskelijat, jotka tietävät vuorovaikutuksesta vähiten.

Teoksen viesti on, että tunneja vuorovaikutustaitoja ei kannata ajatella synnynnäisenä lahjana, vaan niitä voi oppia. Opitutkin taidot vaativat ylläpitämistä.

HELI ANTILA

YTM, KM, EO, lehtori

Tampereen ammattikorkeakoulu 